\title{
PENGEMBANGAN LKPD INKUIRI BERPENDEKATAN NESTED UNTUK MELATIHKAN KETERAMPILAN BERPIKIR KRITIS PADA MATERI LAJU REAKSI
}

\author{
Noera Wahdaniyah $^{1} *$, Bertha Yonata ${ }^{2}$ \\ ${ }^{12}$ Program Studi Pendidikan Kimia, Universitas Negeri Surabaya. Jalan Ketintang \\ Surabaya, Jawa Timur 60231, Indonesia. \\ * Coressponding Author. E-mail: berthayonata@ unesa.ac.id
}

Received: 11 Desember 2020

Accepted: 24 Mei 2021

Published: 24 Mei 2021

doi: $10.29303 /$ cep.v4i1.2274

\begin{abstract}
Penelitian bertujuan untuk mengetahui kelayakan LKPD inkuiri terbimbing berpendekatan nested untuk melatihkan keterampilan berpikir kritis peserta didik pada materi laju reaksi. Desain penelitian pengembangan menggunakan metode 4D meliputi, pendefinisian (define), perencanaan (design), pengembangan (develop), dan penyebaran (disseminate). Namun, penelitian ini hanya sampai tahap pengembangan (develop) saja dan dilakukan uji coba terbatas kepada 12 peserta didik kelas XI IPA 2 SMA Negeri 3 Pamekasan. Instrumen dalam penelitian ini meliputi lembar telaah, lembar validasi, angket respon peserta didik yang didukung dengan lembar observasi aktivitas peserta didik, lembar tes hasil belajar pengetahuan, dan lembar tes hasil belajar keterampilan berpikir kritis. Hasil penelitian menunjukkan bahwa LKPD yang dikembangkan layak digunakan dengan hasil validasi isi, kebahasaan, penyajian, dan kegrafisan mendapatkan presentase sebesar 90\%, 86\%, 90\%, 86\% dalam kategori sangat valid. Respon peserta didik menunjukkan respon positif didukung dengan aktivitas peserta didik yang relevan. LKPD ini memenuhi kriteria keefektifan dengan presentase ketuntasan hasil belajar pengetahuan peserta didik sebesar $100 \%$ dan nilai rata-rata sebesar 93 yang telah melebihi KKM. $N$ gain skor keterampilan berpikir kritis yang diperoleh sebesar 0,91 dalam kategori tinggi. Hasil rata-rata indikator keterampilan berpikir kritis yang diperoleh yaitu interpretasi $97 \%$, inferensi $92 \%$, analisis 93\%, dan ekplanasi 93\% dalam kategori sangat tinggi.
\end{abstract}

Kata Kunci: LKPD, inkuri, pendekatan nested, keterampilan berpikir kritis

\section{Development of Inquiry Student Worksheet with Nested Approach to Train Critical Thinking Skills on Reaction Rate}

\begin{abstract}
This study aims to determine the feasibility of a inquiry student worksheet with a nested approach to train students' critical thinking skills in reaction rate. Design research and development using the $4 D$ method includes defining, designing, developing, and disseminating. However, this research was only up to the development stage but limited trials were carried out on 12 students of class XI IPA 2 SMA Negeri 3 Pamekasan. The instruments used are review sheets, validation, students' response questionnaires, student activity observation sheet, critical thinking skills and students' knowledge tests. The validator's assessment based on the eligibility of the content, language, presentation, and graphic criteria showed the percentage of $90.4 \%, 86,1 \%, 90.0 \%, 85.7 \%$ in the very valid category. Student response shows a positive response supported by relevant student activities. The result of the test was that the learning outcomes of knowledge were $100 \%$ with an average score of 93 which has exceeded the KKM. The N-gain score of critical thinking skills obtained is 0.91 in the high category. The average results of the indicators of critical thinking skills obtained are $97 \%$ interpretation, $92 \%$ inference, $93 \%$ analysis, and $93 \%$ explanation in the very high category.
\end{abstract}




\section{Chemistry Education Practice, 4 (1), 2021 - 20}

Wahdaniyah, Yonata

Keywords: student worksheet, inquiry, nested approach, critical thinking skills

\section{PENDAHULUAN}

Era globalisasi memberi dampak yang cukup luas dalam berbagai aspek kehidupan, termasuk tuntutan dalam penyelenggaraan pendidikan. Pendidikan hendaknya mampu menghasilkan sumber daya manusia yang berkualitas. Untuk dapat mewujudkan sumber daya yang berkualitas maka seseorang juga harus mendapatkan pendidikan yang berkualitas (Wijaya et al., 2016). Namun, kualitas pendidikan di Indonesia masih tergolong rendah. Hal ini dibuktikan dari hasil PISA yang menyatakan bahwa pada tahun 2018 Indonesia menempati urutan ke-72 dari 77 negara pada kategori nilai rata-rata sains dan matematika (OECD, 2019). Oleh karena itu perlu adanya peningkatan kualitas pendidikan di Indonesia agar dapat tercipta sumber daya manusia yang berkualitas terutama pada abad 21 ini.

Pendidikan pada abad 21 dilaksanakan tidak hanya fokus untuk meningkatkan pengetahuan tetapi juga fokus dalam keterampilan berpikir peserta didik. Salah satu keterampilan yang sangat berguna dan sebagai bekal dalam menghadapi kehidupan saat ini dan di masa yang akan datang adalah keterampilan berpikir kritis. Dengan kemampuan berpikir kritis, peserta didik akan berpikir secara rasional, logis, dan mampu memecahkan permasalahan sehingga peningkatan kemampuan berpikir kritis diharapkan akan menciptakan sumber daya manusia yang berkualitas (Wijaya et al., 2016).

Namun, hingga saat ini perhatian pengembangan kemampuan berpikir kritis pada peserta didik masih tergolong rendah sehingga perlu adanya eksplorasi kemampuan berfikir kritis serta pengembangannya (Sulistiani \& Masrukan, 2016). Hal ini bertujuan agar peserta didik dapat meningkatkan pemahamannya pada saat mempelajari materi dalam suatu mata pelajaran kemudian dapat menganalisis dan menyimpulkan materi tersebut. Keterampilan berpikir kritis dapat diterapkan pada semua mata pelajaran, termasuk kimia.

Kimia merupakan bagian dari lmu pengetahuan alam yang pembelajarannya memerlukan pembuktikan suatu konsep. Pembuktian suatu konsep dapat dilakukan melalui percobaan. Salah satu materi yang memerlukan pembuktian melalui percobaan adalah materi laju reaksi. Sesuai dengan keadaan saat ini, maka kompetensi dasar essensial yang harus dicapai peserta didik pada sub materi faktor-faktor yang mempengaruhi laju reaksi adalah KD 3.4 Menjelaskan faktor-faktor yang mempengaruhi laju reaksi menggunakan teori tumbukan dan KD 4.5 Merancang, melakukan, dan menyimpulkan serta menyajikan hasil percobaan faktor-faktor yang mempengaruhi laju reaksi dan orde reaksi (Kemendikbud, 2020). Kompetensi dasar tersebut dipadukan karena KD 4.5 merupakan proses bagi peserta didik untuk menemukan sendiri konsep faktor-faktor yang mempengaruhi laju reaksi melalui percobaan yang dilakukan sehingga dari percobaan tersebut ditemukan konsep yang mendukung tercapainya KD 3.4 .

Mengingat saat ini masih dalam situasi pandemi Covid-19 yang mengharuskan peserta didik belajar secara daring (dalam jaringan) maka pembelajaran melalui percobaan akan sulit dilaksanakan. Tetapi terdapat beberapa solusi agar peserta didik tetap dapat melakukan percobaan sederhana menggunakan alat dan bahan yang tersedia di rumah salah satunya dengan menyajikan sebuah video percobaan yang diakses melalui internet (Belawati, 2020). Video percobaan yang disajikan berisi bagaimana cara melakukan percobaan dengan benar sehingga peserta didik dapat melakukan percobaan secara mandiri dan mampu menemukan konsep sendiri yang dapat meningkatkan pemahaman terhadap materi yang sedang dipelajari. Hal ini sesuai dengan penelitian yang dilakukan Harjono (2015) yang menyatakan bahwa penyajian video dalam proses pembelajaran dapat membimbing peserta didik dalam memahami suatu materi melalui visualisasi. Penyajian video percobaan ini juga menjadi pendukung jalannya proses pembelajaran dengan model pembelajaran yang digunakan yaitu model pembelajaran inkuiri yang dapat membimbing peserta didik dalam menemukan konsep sendiri.

Menurut Nurdyansyah \& Fahyuni (2016) model pembelajaran inkuiri cocok untuk diterapkan dalam pembelajaran mengenai konsep-konsep dan prinsip yang mendasar dalam bidang ilmu tertentu. Oleh karena itu model pembelajaran inkuiri dipilih oleh peneliti karena cocok untuk diterapkan pada sub materi faktorfaktor yang mempengaruhi laju reaksi. Model pembelajaran inkuiri yang diterapkan dalam penelitian ini adalah model pembelajaran inkuiri terbimbing menurut Arent. Model pembelajaran inkuiri terbimbing menurut Arent terdiri dari 


\section{Chemistry Education Practice, 4 (1), 2021 - 21}

Wahdaniyah, Yonata

enam sintaks yaitu memusatkan perhatian dan menjelaskan proses inkuiri, menyajikan masalah inkuiri dan fenomena, merumuskan hipotesis untuk menjelaskan permasalahan atau fenomena, mengumpulkan data untuk menguji hipotesis, merumuskan penjelasan atau kesimpulan, merefleksikan situasi masalah dan proses berfikir (Arends, 2012). Model pembelajaran inkuiri terbimbing tidak hanya memperdayakan kimia sebagai produk saja tetapi juga mampu memperdayakan kimia sebagai proses serta menekankan pada proses berpikir kritis untuk mencari dan menemukan sendiri jawaban dari suatu permasalahan yang ada (Sutama et al., 2014).

Model pembelajaran inkuiri terbimbing mempunyai kelemahan yaitu peserta didik harus memiliki pengetahuan awal agar pembelajaran berjalan dengan baik, peserta didik harus memiliki kesiapan mental, dan fasilitas untuk melakukan percobaan harus terpenuhi (Sutama et al., 2014). Untuk meminimalkan kelemahan tersebut, dalam mempelajari kimia peserta didik harus dapat mengolah dan menafsirkan data (pengorganisasian data). Oleh sebab itu, peneliti membutuhkan adanya suatu integrasi pembelajaran inkuiri terbimbing dengan pembelajaran lainnya agar pembelajaran lebih optimal dalam melatihkan keterampilan berpikir kritis peserta didik .

Salah satu pendekatan pembelajaran yang mempunyai potensi sesuai kelemahan dari pembelajaran inkuiri terbimbing adalah pendekatan nested. Hal tersebut dikarenakan pendekatan nested merupakan suatu integrasi kurikulum atau pembelajaran yang memanfaatkan keterampilan peserta didik untuk mendapatkan suatu konsep dengan cara menyarang. Sejalan dengan itu, pendekatan nested merupakan pendekatan dalam pembelajaran yang memadukan keterampilan berpikir (thinking skill), keterampilan sosial (sosial skill), dan keterampilan mengorganisasi (organizing skill) (Kusuma et al., 2015). Pelajaran sains dan matematika dapat memadukan keterampilan berpikir (thinking skills) dan keterampilan mengorganisasi (organzing skills) (Kusuma et al., 2015). Keterampilan mengorganisasi (organzing skills) diantaranya yaitu membuat tabel dan grafik. Pengetahuan interpretasi grafik dan data dalam pembelajaran sains sangat penting bagi peserta didik. Namun, banyak peserta didik sekolah dasar, menengah hingga mahasiswa yang masih memiliki kesulitan dalam menggunakan, menafsirkan, dan memahami grafik dan data, untuk itu kompetensi ini perlu dilatihkan (Mustain, 2015). Oleh karena itu diperlukan suatu bahan ajar yang sesuai dengan permasalahan yang telah disebutkan guna mencapai ketuntasan kompetensi yang ditetapkan.

Salah satu bahan ajar yang digunakan dalam proses pembelajaran adalah lembar kerja peserta didik atau LKPD. LKPD dipilih karena memiliki fungsi yang dapat mempermudah peserta didik dalam memahami materi yang diberikan sehingga dapat membantu peserta didik baik dalam pembelajaran daring (dalam jaringan) maupun luring (luar jaringan). Selain itu, LKPD juga berperan penting dalam proses pembelajaran yang fungsinya dapat meningkatkan kemampuan peserta didik dalam memecahkan masalah (Prastowo, 2015). Peserta didik diharapkan dapat terlatih dalam keterampilan berpikir kritis melalui penggunaan LKPD yang relevan. Hal ini diperkuat dengan penelitian yang dilakukan oleh Apriyana, N., Herlina \& Abdurrahman (2019) yang menyatakan bahwa penggunaan LKPD untuk meningkatkan keterampilan berpikir kritis sangat membantu dalam penguasaan konsep peserta didik yang ditandai dengan respon peserta didik yang positif.

Berdasarkan latar belakang masalah di atas, maka peneliti perlu melakukan penelitian dengan judul "Pengembangan LKPD Inkuiri Berpendekatan Nested untuk Melatihkan Keterampilan Berpikir Kritis pada Materi Laju Reaksi”.

\section{METODE}

Jenis penelitian ini merupakan penelitian pengembangan dalam bidang pendidikan yaitu pengembangan LKPD. Pengembangan LKPD ini menggunakan metode pengembangan 4D (define, desain, develop, and disseminate). Pada penelitian ini hanya menggunakan metode 4D sampai tahap ketiga saja sedangkan tahap penyebaran (desiminate) tidak dilakukan namun dilakukan uji coba terbatas untuk mengetahui kepraktisan dan keefektifan dari LKPD yang dikembangkan agar menghasilkan bahan ajar yang layak. LKPD ini diujicoba kepada 12 peserta didik kelas XI IPA 2 SMA Negeri 3 Pamekasan semester ganjil tahun ajaran 2020/2021 pada tanggal 9-28 November 2020. Tahap penelitian dapat dilihat pada Gambar 1 berikut. 


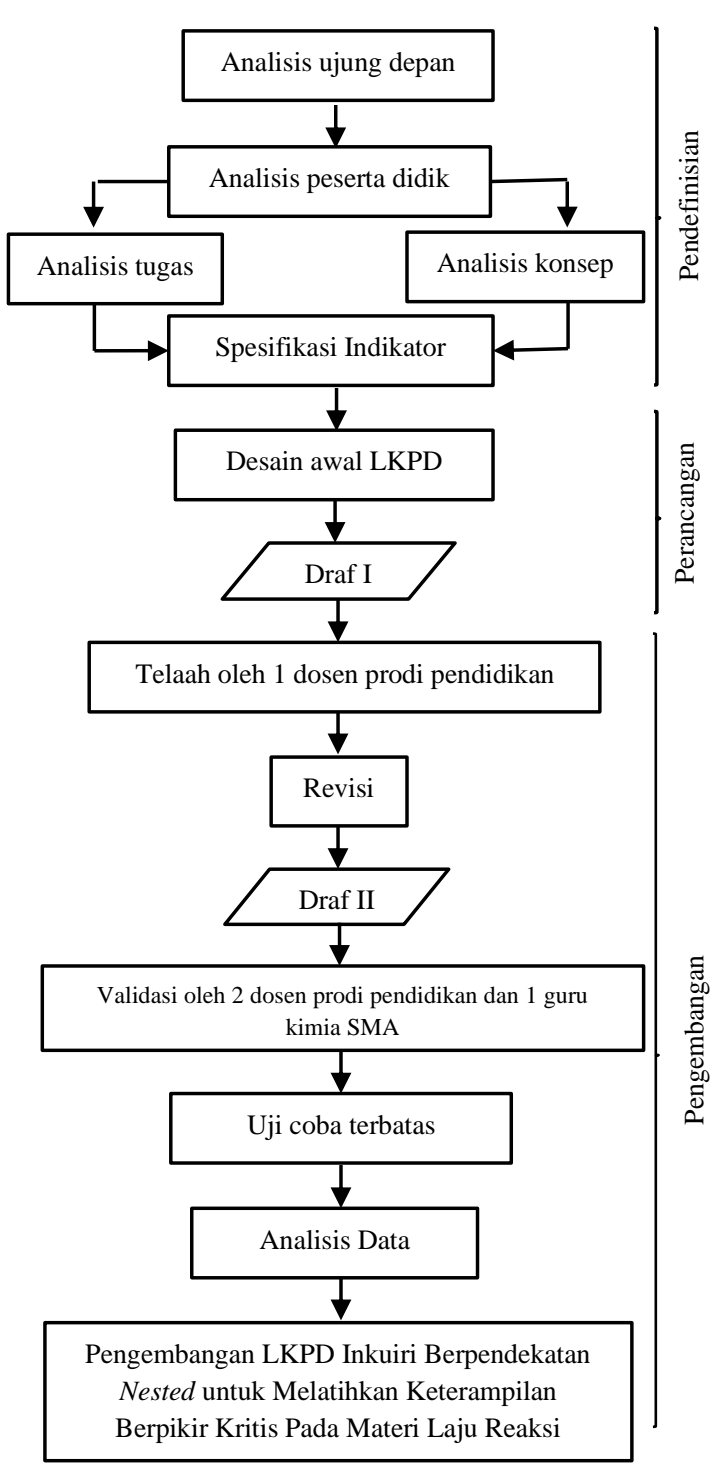

Gambar 1. Tahap Metode Pengembangan 4D

Instrumen yang digunakan dalam penelitian ini meliputi, lembar telaah, lembar validasi, angket respon peserta didik yang didukung dengan lembar observasi aktivitas peserta didik, lembar tes hasil belajar pengetahuan, dan lembar tes hasil belajar keterampilan berpikir kritis.

Teknik pengumpulan data berupa kelayakan LKPD ditentukan oleh data validitas yang meliputi validitas isi dan validitas konstruk (kebahasaan, penyajian, dan kegrafisan). Validasi dilakukan oleh dua dosen kimia FMIPA Unesa dan satu guru kimia SMA Negeri 3 Pamekasan. Kepraktisan dinyatakan dengan hasil angket respon peserta didik yang diisi oleh 12 peserta didik yang didukung dengan hasil observasi aktivitas peserta didik. Sedangkan keefektifan dinyatakan dengan hasil penilaian tes hasil belajar pengetahuan dan keterampilan berpikir kritis setelah melalui proses pembelajaran menggunakan LKPD yang dikembangkan.

\section{Analisis Hasil Lembar Telaah dan Validasi}

Hasil telaah dianalisis secara deskriptif. Hasil validasi setiap kompenen dalam lembar validasi dianalisis menggunakan skala Likert seperti pada Tabel 1 berikut.

Tabel 1. Skala Likert

\begin{tabular}{cc}
\hline Penilaian & Nilai Skala \\
\hline Sangat Baik & 5 \\
Baik & 4 \\
Cukup Baik & 3 \\
Kurang Baik & 2 \\
Tidak Baik & 1 \\
\hline
\end{tabular}

Selanjutnya, hasil yang diperoleh dari data validasi dihitung presentasenya menggunakan rumus berikut.

$$
\begin{gathered}
\text { Presentase }=\frac{\sum \text { Skor Pengumpulan Data }}{\sum \text { Skor kriterium }} \\
\text { Kemudian dari presentase }
\end{gathered}
$$
dikatagorikan berdasarkan kriteria pada Tabel 2 berikut.

Tabel 2. Persentase Skala Likert

\begin{tabular}{cc}
\hline Kategori & Nilai Skala $(\%)$ \\
\hline Sangat Valid & $81-100$ \\
Valid & $61-80$ \\
Cukup Valid & $41-60$ \\
Kurang Valid & $21-40$ \\
Tidak Valid & $0-20$ \\
\hline
\end{tabular}

(Riduwan, 2015)

LKPD dikatakan layak digunakan dalam pembelajaran apabila hasil presentase yang didapat $\geq 61 \%$ dengan kriteria valid atau sangat valid (Riduwan, 2015).

\section{Analisis Hasil Angket Respon Peserta Didik}

Hasil angket respon peserta didik untuk menyatakan kepraktisan LKPD yang dikembangkan dianalisis menggunakan skala Guttman yang disajikan pada Tabel 3 berikut.

Tabel 3. Skala Guttman

\begin{tabular}{cc}
\hline Jawaban & Nilai \\
\hline Ya & 1 \\
Tidak & 0 \\
\hline
\end{tabular}

(Riduwan, 2015)

Selanjutnya, data yang diperoleh dihitung presentasenya menggunakan rumus berikut.

Presentase $(\%)=\frac{\sum \text { Skor yang diperoleh }}{\sum \text { Skor maksimal }} \times 100 \%$

Hasil presentase kemudian diinterpretasikan sesuai dengan Tabel 4 berikut. 
Tabel 4. Interpretasi Skor Respon Peserta Didik

\begin{tabular}{cr}
\hline Kategori & Nilai Skala $(\%)$ \\
\hline Sangat merespon & $81-100$ \\
Merespon & $61-80$ \\
Kurang merespon & $41-60$ \\
Tidak merespon & $21-40$ \\
Sangat tidak merespon & $0-20$
\end{tabular}

(Riduwan, 2015)

LKPD dikatakan praktis apabila respon peserta didik mencapai presentase $\geq 61 \%$.

\section{Analisis Hasil Observasi Aktivitas Peserta Didik}

Hasil observasi aktivitas peserta didik dianalisis secara deskriptif kuantitatif. Data hasil observasi kemudian digunakan untuk data pendukung angket respon peserta didik. Presentase tiap aktivitas peserta didik dihitung menggunakan rumus

$$
\text { \%aktivitas }=\frac{\sum \text { peserta didik yang melakukan }}{\sum \text { seluruh peserta didik }}
$$

Hasil observasi aktivitas peserta didik dikatakan mendukung angket respon peserta didik jika presentase aktivitas peserta didik yang relevan lebih besar dari pada aktivitas yang tidak relevan.

\section{Analisis Hasil Tes Pengetahuan dan Keterampilan Berpikir Kritis Peserta Didik}

Hasil belajar tes pengetahuan dihitung menggunakan rumus:

$$
\text { HB pengetahuan }=\frac{\sum \text { Skor yang diperoleh }}{\sum \text { Skor maksimal }} \times 100
$$

Peserta didik dikatakan menguasai materi apabila didapatkan hasil belajar $\geq 75$ sesuai dengan kriteria ketuntasan minimum (KKM) di SMA Negeri 3 Pamekasan.

Analisis data hasil penilaian keterampilan berpikir kritis peserta didik diolah secara deskriptif kuantitatif. Analisis data ini dilakukan terhadap kompenen keterampilan berpikir kritis yaitu interpretasi, inferensi, analisis, dan eksplanasi. Setiap komponen dari berpikir kritis dihitung dengan menggunakan rumus sebagai berikut

(\%) komponen $\mathrm{KBK}=\frac{\text { skor } \text { yang diperoleh }}{\text { skor total }} \times 100$

Presentase tiap komponen berpikir kritis tersebut selanjutnya diinterpretasikan sesuai dengan Tabel 5 berikut.
Tabel 5. Kriteria Interpretasi Skor

\begin{tabular}{cc}
\hline Kategori & Nilai Skala $(\%)$ \\
\hline Sangat tinggi & $90-100$ \\
Tinggi & $75-89$ \\
Normal & $55-74$ \\
Rendah & $31-54$ \\
Sangat rendah & $0-30$ \\
\hline & (Riduwan, 2015)
\end{tabular}

Setiap komponen berpikir kritis dapat dikatakan berhasil dilatihkan apabila didapat presentase $\geq 75 \%$ dengan kategori tinggi atau sangat tinggi

Sedangkan untuk analisis pretest dan posttest individu dianalisis melalui perhitungan $n$-gain skor untuk mengetahui seberapa besar perbedaan antara nilai pretest dan posttest keterampilan berpikir kritis setelah menggunakan LKPD yang dikembangkan. Persamaan yang digunakan untuk menghitung $n$-gain skor adalah sebagai berikut

$$
\mathrm{N}-\text { gain } \text { skor }=\frac{\text { nilai posttest-nilai prettest }}{\text { nilai maksimal-nilai pretest }}
$$

Selanjutnya $n$-gain skor yang diperoleh diinterpretasikan sesuai dengan Tabel 6 berikut.

Tabel 6. Kriteria Tingkat $N$-gain skor

\begin{tabular}{cl}
\hline Skor N-gain & Kriteria \\
\hline $\mathrm{g}<0,3$ & Rendah \\
$0,3 \leq \mathrm{g}<0,7$ & Sedang \\
$\mathrm{g} \geq 0,7$ & Tinggi \\
\hline & (Hake, 1998)
\end{tabular}

Keterampilan berpikir kritis dikatakan berhasil dilatihkan apabila n-gain skor yang diperoleh peserta didik $\geq 0,3$ dengan kriteria sedang atau tinggi.

\section{HASIL DAN PEMBAHASAN}

Hasil Penelitian yang berjudul "Pengembangan LKPD Inkuiri Berpendekatan Nested untuk Melatihkan Keterampilan Berpikir Kritis pada Materi Laju Reaksi” bertujuan untuk mengembangkan LKPD yang layak digunakan terutama pada masa pandemi Covid-19 ini. Salah satu solusi yang mendukung proses pembelajaran pada masa pandemi Covid-19 adalah pembelajaran secara daring (online) (Handarini, 2020). Pembelajaran secara daring dapat dilakukan melalui google meet untuk tatap muka dan google form untuk penugasannya (Rakhmawati \& Siregar, 2020).

Desain pengembangan $4 \mathrm{D}$ yang digunakan dalam penelitian ini adalah pendefinisian (define), perancangan (design), dan pengembangan (develop). Penjabaran dari tiap tahapan adalah sebagai berikut 


\section{Chemistry Education Practice, 4 (1), 2021 - 24}

Wahdaniyah, Yonata

\section{Tahap Pendefinisian (Define)}

Tahap pendefinisian ini memiliki tujuan yaitu menetapkan serta mendefinisikan syaratsyarat penyusunan LKPD. Pada tahap ini dilakukan kegiatan analisis sesuai dengan kebutuhan meliputi analisis ujung depan, analisis peserta didik, analisis tugas, analisis konsep dan spesifikasi indikator (Damaianti et al., 2019). Tahap pendefinisian ini diawali dengan analisis ujung depan yang bertujuan memunculkan dan menetapkan masalah dasar dihadapi oleh guru dan peserta didik dalam pembelajaran kimia. Kemudian dilanjutkan dengan analisis peserta didik bertujuan untuk menguji karakteristik peserta didik sebagai ilustrasi untuk mendesain LKPD. Analisis tugas diperlukan untuk menganalisis kompetensi dasar (KD) dan indikator pembelajaran. Analisis konsep dilakukan dengan mengidentifikasi konsepkonsep utama yang akan diajarkan pada materi laju reaksi khususnya faktor-faktor yang mempengaruhi laju reaksi yang disusun secara sistematis dan merinci konsep-konsep yang

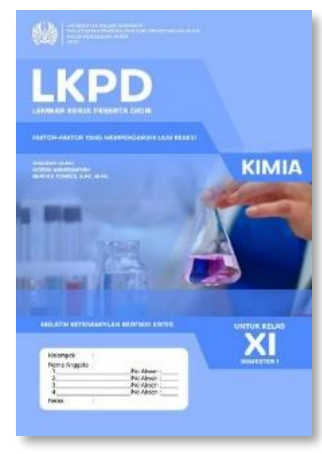

(a)

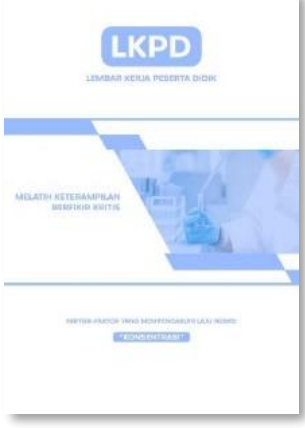

relevan. Spesifikasi indikator berguna untuk mengkonversi tujuan dasar dari analisis tugas dan analisis konsep menjadi tujuan pembelajaran khusus yang dinyatakan dengan tingkah laku, meliputi indikator hasil belajar yang akan dicapai peserta didik dalam materi laju reaksi.

\section{Tahap Perancangan (Design)}

Pada tahap perancangan dihasilkan prototipe atau rancangan awal LKPD. LKPD yang dikembangkan ada 4 bagian yang dirancang masing-masing memuat 1 faktor yang mempengaruhi laju reaksi. Tahapan pembelajaran dalam LKPD menyesuaikan tahapan inkuiri terbimbing menurut Arent dengan pendekatan nested. Tiap tahapan juga terdapat komponen untuk melatihkan keterampilan berpikir kritis menurut Facione. Keterampilan berpikir kritis yang dilatihkan yaitu interpretasi, inferensi, analisis, dan eksplanasi (Facione, 2011).
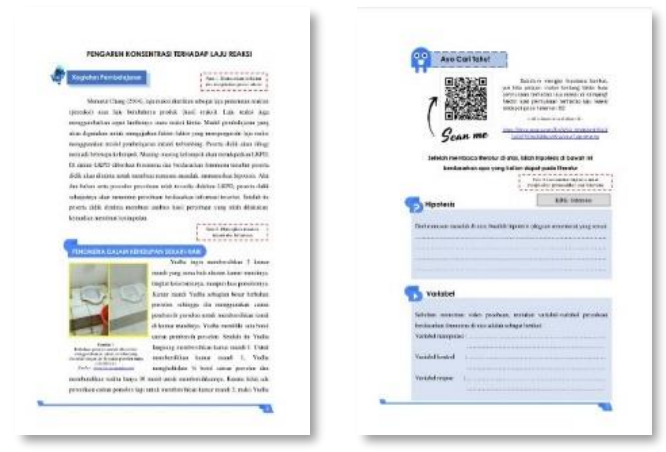

(b)

Gambar 2. (a) Tampilan Cover Utama LKPD dan Sub Cover Faktor Konsentrasi (b) Tampilan Isi LKPD

Gambar 2 di atas merupakan cuplikan prototipe yang dibuat pada tahapan perancangan sesuai dengan analisis yang dilakukan pada tahap sebelumnya sehingga dihasilkan draf I.

\section{Tahap Pengembangan (Develop)}

Pengembangan ini bertujuan untuk menghasilkan produk yaitu lembar kerja peserta didik dengan tujuan yang telah dirumuskan sebagai bahan ajar agar lebih sempurna melalui revisi dan saran dari para ahli. Proses yang dilaksanakan dalam tahap ini adalah proses telaah, validasi yang diikuti revisi kemudian dilakukan uji coba terbatas menggunakan LKPD hasil revisi. Uraian proses yang dilaksanakan pada tahap pengembangan adalah sebagai berikut:

Telaah

Sebelum divalidasi oleh validator, LKPD ditelaah terlebih dahulu untuk mendapatkan saran atau komentar dari satu dosen pembimbing. Hasil yang didapat LKPD sudah mencakup semua komponen penilaian yaitu isi, kebahasaan, penyajian, dan kegrafisan, namun terdapat 3 poin yang harus diperbaiki yaitu memperbaiki fenomena, menambah pengantar/penjelasan pada setiap tahapan yang dikerjakan pada LKPD, dan memperbaiki komponen yang berhubungan dengan pendekatan nested. Saran atau komentar 


\section{Chemistry Education Practice, 4 (1), 2021 - 25}

Wahdaniyah, Yonata

kemudian diperbaiki pada tahap revisi untuk menghasilkan draf II.

Validitas

Validitas LKPD yang dikembangkan ditinjau dari validitas isi, kebahasaan, penyajian, dan kegrafisan (BSNP, 2014). Proses validasi diperlukan untuk perbaikan draf II LKPD yang dikembangkan berdasarkan saran/komentar yang telah diberikan oleh ahli yaitu dua dosen kimia FMIPA Unesa dan satu guru kimia SMA Negeri 3 Pamekasan. Kemudian LKPD diperbaiki sesuai dengan saran/komentar yang diberikan untuk digunakan pada uji coba terbatas. Adapun rekapitulasi hasil dari validasi dapat dilihat pada Tabel 7 berikut.

Tabel 7. Hasil Validasi

\begin{tabular}{ccc}
\hline $\begin{array}{c}\text { Kriteria } \\
\text { yang Dinilai }\end{array}$ & Presentase & Kategori \\
\hline Isi & $90 \%$ & Sangat Valid \\
Kebahasaan & $86 \%$ & Sangat Valid \\
Penyajian & $90 \%$ & Sangat Valid \\
Kegrafisan & $86 \%$ & Sangat Valid \\
\hline
\end{tabular}

Berdasarkan Tabel 7 di atas, kriteria kevalidan isi LKPD yang dikembangkan mendapatkan nilai $90 \%$ dalam kategori sangat valid karena presentase yang didapat $\geq 61 \%$ (Riduwan, 2015), hal ini menunjukkan bahwa LKPD yang dikembangkan telah memenuhi kriteria kevalidan isi menurut BNSP yang meliputi kesesuaian materi laju reaksi dengan kurikulum 2013, kompetensi inti (KI), kompetensi dasar (KD), indikator pembelajaran, dan tujuan pembelajaran sudah jelas. Selain itu kesesuaian isi LKPD dengan model pembelajaran inkuiri terbimbing mendapatkan presentase sebesar $89 \%$ dalam kategori sangat valid yang berarti LKPD yang dikembangkan telah sesuai dengan tahapan model pembelajaran inkuiri terbimbing yang digunakan. Kesesuaian isi LKPD dengan keterampilan berpikir kritis mendapatkan presentase sebesar $89 \%$ dalam kategori sangat valid yang berarti LKPD yang dikembangkan memuat indikator keterampilan berpikir kritis yang akan dilatihkan, serta kesesuaian isi LKPD dengan pendekatan nested yang digunakan mendapatkan presentase sebesar 93\% yang berarti LKPD yang dikembangkan telah sesuai dengan kriteria pendekatan nested. Kebenaran konsep video dan e-book yang disajikan dalam LKPD telah sesuai dengan materi yang dibuktikan dengan hasil validasi yang diperoleh sebesar $80 \%$ dalam kategori valid.

Kriteria kebahasaan LKPD yang dikembangkan mendapatkan presentase sebesar
86\% dalam kategori sangat valid karena presentase yang didapat $\geq 61 \%$ (Riduwan, 2015). Hal ini menandakan bahwa LKPD dikembangkan telah menggunakan bahasa yang baik dan benar, efektif dan efesien, serta menggunakan istilah yang mudah dipahami sehingga dapat menyampaikan pesan. Anak dalam usia 16-18 berada pada tahap operasional formal sehingga penggunaan bahasa yang mudah dipahami sangat dianjurkan (Santrock, 2008).

Kriteria penyajian LKPD yang dikembangkan mendapatkan presentase sebesar 90\% dalam kategori sangat valid karena presentase yang didapat $\geq 61 \%$ (Riduwan, 2015). Hal ini menunjukkan bahwa LKPD yang dikembangkan sudah sesuai dengan Depdiknas (2008) yang menyatakan bahwa kriteria penyajian urutan materi dalam LKPD harus disajikan secara sistematis dan jelas. Keruntutan penyajian dalam LKPD mendapatkan presentase sebesar 93\% dalam kategori sangat valid. Ilustrasi atau gambar yang disajikan dalam LKPD relevan dengan materi laju reaksi mendapat presentase sebesar $80 \%$ dalam kategori valid.

Kriteria kegrafisan LKPD yang dikembangkan mendapatkan presentase sebesar $86 \%$ dalam kategori sangat valid karena presentase yang didapat $\geq 61 \%$ (Riduwan, 2015) LKPD dikembangkan dengan menggunakan cover yang menarik, menggunakan font dan ukuran teks yang mudah dibaca, tata letak teks dan gambar serasi, serta istilah, rumus, dan simbol dinyatakan dengan jelas. Depdiknas (2008) menyatakan bahwa tipografi huruf yang baik akan memudahkan pembaca dalam memahami suatu bacaan.

\section{Kepraktisan LKPD}

Angket respon peserta didik digunakan untuk mengetahui kepraktisan LKPD yang dikembangkan. Data hasil respon peserta didik dapat dilihat pada Tabel 8 berikut.

Tabel 8. Hasil Angket Respon

\begin{tabular}{|c|c|c|}
\hline $\begin{array}{c}\text { Kriteria } \\
\text { yang Dinilai }\end{array}$ & $\begin{array}{c}\text { Presentase } \\
\text { yang } \\
\text { Diperoleh }\end{array}$ & Kategori \\
\hline Isi & $100 \%$ & Sangat Merespon \\
\hline Kebahasaan & $100 \%$ & Sangat Merespon \\
\hline Penyajian & $100 \%$ & Sangat Merespon \\
\hline Kegrafisan & $100 \%$ & Sangat Merespon \\
\hline
\end{tabular}

Berdasarkan data hasil angket respon peserta didik, LKPD yang dikembangkan sudah memenuhi kriteria kepraktisan karena pada masing-masing komponen pada angket respon mendapatkan presentase sebesar $100 \%$ dalam 
kategori sangat merespon artinya penyajian dalam LKPD mudah dipahami. Fenomena yang disajikan dalam LKPD dapat menumbuhkan rasa ingin tahu peserta didik sehingga dapat mempermudah peserta didik memahami materi yang diajarkan. Video dalam LKPD dapat diakses dengan mudah sehingga peserta didik dapat mengetahui bagaimana cara melakukan percobaan ketika pembelajaran daring (online) dan peserta didik dapat melakukan percobaan secara mandiri di rumah. Selain itu LKPD dapat melatihkan bagaimana cara mengorganisasi tabel dan grafik dengan benar. Pengorganisasian tabel dan grafik yang benar dapat membantu peserta didik dalam menganalisis data (Kusuma et al., 2015).

Hasil angket respon ini selaras dengan hasil observasi aktivitas peserta didik tiap kali menggunakan LKPD yang dikembangkan pada pertemuan 1 dan 2. Hasil observasi yang menunjukkan bahwa peserta didik lebih banyak melakukan aktivitas yang relevan dari pada aktivitas yang tidak relevan. Hasil observasi aktivitas peserta didik pada pertemuan 1 dan 2 dapat dilihat pada diagram yang disajikan pada Gambar 3 berikut ini.

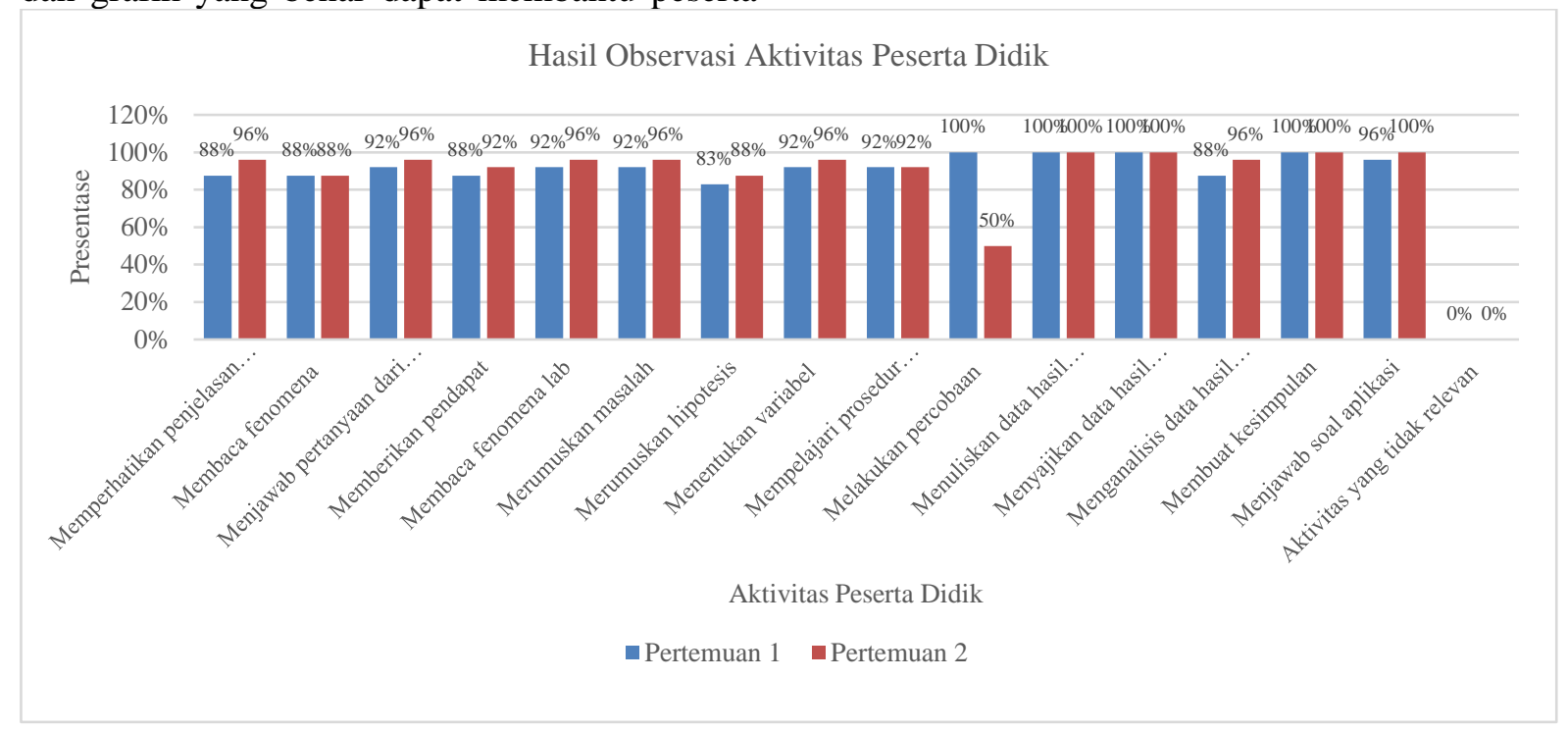

Gambar 3. Diagram Aktivitas Peserta Didik

Berdasarkan hasil observasi aktivitas peserta didik pada Gambar 4 di atas, dapat dilihat bahwa aktivitas melakukan percobaan pada pertemuan kedua memperoleh presentase sebesar $50 \%$, hal ini dikarenakan pada pertemuan kedua ketika membahas LKPD 4 yaitu faktor katalis, tidak dilaksanakan kegiatan percobaan seperti LKPD 1, 2, dan 3 tetapi hanya menonton video saja dikarenakan bahan yang diperlukan untuk fakor katalis tidak tersedia di lingkungan sekitar dan harus dilakukan di laboratorium sehingga tidak memungkinkan jika melakukan percobaan di rumah dalam situasi pembelajaran daring (online). Meskipun demikian, proses pembelajaran menggunakaan video dapat mengoptimalkan partisipasi peserta didik dalam proses pembelajaran apalagi jika dilakukan diskusi kelompok dalam mengerjakan lembar kerja peserta didik, hal ini akan memberikan keuntungan bagi peserta didik agar dapat bertukar pikiran dengan teman sekelompok sehingga dapat meningkatkan pemahaman peserta didik (Kurniawan, 2016).

\section{Keefektivan LKPD}

Keefektivan LKPD yang dikembangkan diperoleh dari tes hasil belajar peserta didik. Terdapat dua tes hasil belajar yaitu tes hasil belajar pengetahuan dan tes hasil belajar keterampilan berpikir kritis. Dengan adanya tes ini peneliti dapat mengetahui sejauh mana pemahaman konsep dan keterampilan berpikir kritis peserta didik setelah melalui pembelajaran menggunakan LKPD yang dikembangkan. Peserta didik mengerjakan soal pretest dan posttest pada soal yang sama sebanyak 16 soal essay untuk mengukur keterampilan berpikir kritis peserta didik, sedangkan untuk mengetahui pemahaman konsep, peserta didik hanya mengerjakan posttest yang berbentuk pilihan ganda di akhir pembelajaran setelah melakukan 
pembelajaran menggunakan LKPD yang dikembangkan.

Dari hasil posttest pengetahuan yang diberikan kepada 12 peserta didik, diperoleh nilai $\geq 75$ dengan rata-rata hasil yang diperoleh sebesar 93. Presentase ketuntasan hasil belajar pengetahuan peserta didik sebesar $100 \%$. Hal ini menujukkan bahwa peserta didik sudah tuntas dan memahami konsep yang diberikan mengenai faktor-faktor yang mempengaruhi laju reaksi.

Data hasil belajar keterampilan berpikir kritis digunakan untuk mengetahui keefektifan LKPD yang dikembangkan dalam melatihkan keterampilan berpikir kritis. Berdasarkan hasil nilai pretest yang diperoleh peserta didik, tidak ada satupun indikator keterampilan berpikir kritis yang tuntas. Hal ini dikarenakan dari hasil wawancara yang telah dilakukan, keterampilan berpikir kritis jarang dilatihkan di sekolah tersebut Setelah peserta didik melaksanakan pembelajaran menggunakan LKPD berbasis inkuiri terbimbing dengan pendekatan nested untuk melatihkan keterampilan berpikir kritis pada materi laju reaksi, hasil nilai posttest peserta didik mengalami peningkatan dibandingkan dengan nilai pretest. Hasil perbandingan pretest dan posttest keterampilan berpikir kritis peserta didik setelah melakukan pembelajaran menggunkan LKPD yang dikembangkan dapat dilihat pada Gambar 4 berikut.

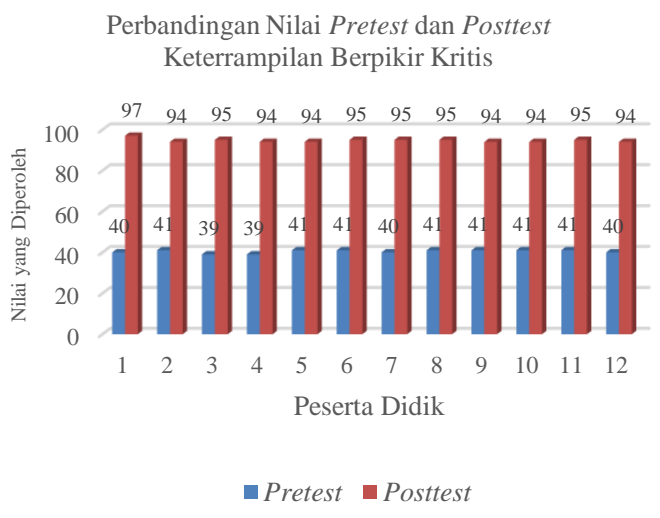

Gambar 4. Perbandingan Pretest dan Posttest Keterampilan Berpikir Kritis

Sedangkan Hasil postest setiap indikator keterampilan berpikir kritis disajikan dalam Tabel 9 berikut.

Tabel 9. Postest Setiap Indikator Keterampilan Berpikir Kritis

\begin{tabular}{ccc}
\hline Indikator & $\begin{array}{c}\text { Presentase } \\
\text { yang } \\
\text { Diperoleh }\end{array}$ & Kategori \\
\hline Interpretasi & $97 \%$ & Sangat tinggi \\
Inferensi & $92 \%$ & Sangat tinggi \\
\hline
\end{tabular}

\begin{tabular}{ccc} 
Analisis & $93 \%$ & Sangat tinggi \\
Eksplanasi & $93 \%$ & Sangat tinggi \\
\hline
\end{tabular}

Berdasarkan Tabel 9 di atas dapat diketahui setiap indikator keterampilan berpikir kritis mendapatkan nilai lebih dari $90 \%$ dalam kategori sangat tinggi yang dapat diartikan bahwa setiap indikator keterampilan berpikir kritis telah terlatihkan setelah menggunakan LKPD yang dikembangkan. Hasil ini selaras dengan penelitian yang dilakukan oleh Prasetyowati \& Suyatno (2016) yang menyebutkan penggunaan LKPD berbasis inkuiri terbimbing dapat meningkatan penguasaan konsep dan keterampilan berpikir kritis peserta didik pada materi larutan penyangga.

Analisis peningkatan hasil belajar keterampilan berpikir kritis peserta didik setelah menggunakaan LKPD yang dikembangkan menggunakan analisis $n$-gain skor yang bertujuan untuk mengetahui peningkatan keterampilan berpikir kritis pada setiap peserta didik (Hake, 1998). $N$-gain skor setiap peserta didik dapat dilihat pada diagram yang disajikan pada Gambar 5 berikut.

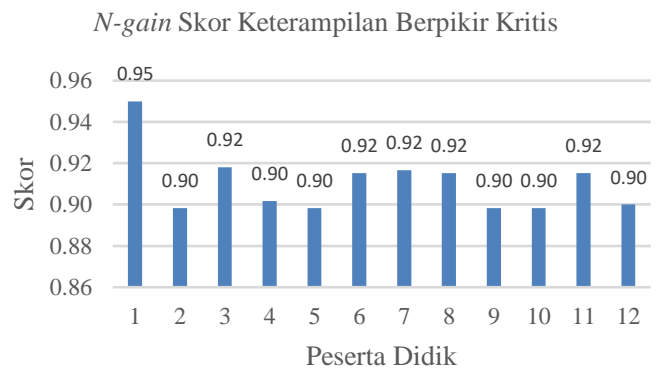

Gambar 5. N-gain Skor Keterampilan Berpikir Kritis

Dari hasil analisis data hasil belajar keterampilan berpikir kritis, rata- rata $n$-gain skor yang diperoleh sebesar 0,91 dalam kategori tinggi karena hasil yang diperoleh $\geq 0,3$. Dengan meningkatnya hasil belajar keterampilan berpikir kritis peserta didik dapat diartikan bahwa setelah menggunakan LKPD yang dikembangkan keterampilan berpikir kritis peserta didik sudah terlatih dengan baik dan LKPD yang dikembangkan telah memenuhi kriteria keefektifan. LKPD ini dikembangkan dengan model pembelajaran inkuiri terbimbing dimana rangkaian kegiatan pembelajaran inkuri terbimbing menekankan pada proses berpikir kritis untuk mencari dan menemukan sendiri jawaban dari suatu permasalahan yang ditanyakan, sehingga peserta didik lebih aktif dalam kegiatan pembelajarannya dan dapat mengembangkan daya intelektualnya. Sesuai 


\section{Chemistry Education Practice, 4 (1), 2021 - 28}

Wahdaniyah, Yonata

dengan penelitian Munfaricha \& Ismono (2019) bahwa pembelajaran menggunakan LKPD berbasis inkuiri terbimbing efektif untuk meningkatkan keterampilan berpikir kritis peserta didik.

Pada penelitian ini n-gain skor yang diperoleh lebih tinggi dari pada $n$-gain skor yang diperoleh Firdaus \& Wilujeng (2018) yang hanya memperoleh n-gain skor sebesar 0,43. Hal tersebut dikarenakan LKPD yang dikembangkan memadukan model pembelajaran inkuiri terbimbing dengan pendekatan nested. Pendekatan nested yang digunakan dalam LKPD ini dapat melatihkan keterampilan peserta didik dalam mengorganisasi tabel dan grafik sesuai dengan data sehingga mendukung peserta didik dalam menganalisis suatu fenomena dalam LKPD (Basuki \& Novita, 2019). Selain itu, LKPD yang dikembangkan juga menyajikan $e$ book dan video percobaan yang diakses dengan men-scan barcode atau link yang tersedia dalam LKPD. Hal ini sangat mendukung proses pembelajaran dengan model pembelajaran inkuiri terbimbing yang dilakukan secara daring (online) sehingga peserta didik akan tetap dapat melakukan percobaan di rumah dan pembelajaran akan lebih bermakna serta kemampuan peserta didik juga akan meningkat.

Dari dua tes hasil belajar yaitu tes hasil belajar pengetahuan dan tes hasil belajar keterampilan, keduanya menunjukan hasil yang tuntas sehingga dapat disimpulkan bahwa LKPD berbasis inkuiri terbimbing dengan pendekatan nested untuk melatihkan keterampilan berpikir kritis peserta didik pada materi laju reaksi yang dikembangkan memenuhi kriteria keefektifan sesuai dengan hasil tes yang diperoleh.

\section{SIMPULAN}

Berdasarkan hasil penelitian yang dilakukan, dapat disimpulkan bahwa LKPD inkuiri terbimbing dengan pendekatan nested untuk melatihkan keterampilan berpikir kritis peserta didik layak untuk digunakan sebagai bahan ajar ditinjau dari hasil validitas isi, kebahasaan, penyajian, dan kegrafisan yang mendapatkan hasil sangat valid. Kepraktisan LKPD menunjukkan hasil respon yang positif yang didukung dengan aktivitas relevan yang dilakukan peserta didik lebih tinggi dari pada aktivitas yang tidak relevan. Sedangkan keefektifan LKPD telah memenuhi kriteria keefektifan yang ditunjukkan dengan persentase ketuntasan hasil belajar pengetahuan peserta didik sebesar $100 \%$ dan hasil n-gain skor keterampilan berpikir kritis yang diperoleh dalam kategori tinggi. Selain itu pendekatan nested yang digunakan juga melatihkan peserta didik dalam mengorganisasi tabel dan grafik berdasarkan hasil percobaan yang dilakukan sehingga peserta didik dapat menganalisis data dengan baik dan nilai posttest yang diperoleh juga meningkat. Penelitian ini merupakan pengembangan LKPD yang memadukan model pembelajaran inkuiri terbimbing dengan pendekatan nested hanya pada keterampilan mengorganisasi saja, oleh karena itu perlu dilakukan penelitian lanjutan seperti memadukan model pembelajaran inkuiri terbimbing dengan pendekatan nested pada aspek keterampilan mengorganisasi dan keterampilan sosial.

\section{DAFTAR PUSTAKA}

Apriyana, N., Herlina, K., \& Abdurrahman. (2019). Pengembangan Lembar Kerja Siswa Berbasis Inkuiri Terbimbing untuk Meningkatkan Kemampuan Berpikir Kritis. Jurnal Pendidikan Fisika Dan Teknologi, 2(7), 92-96.

Arends, R. I. (2012). Learning to Teach Ninth Edition. New York: McGraw-Hill Companies.

Basuki, B. B., \& Novita, D. (2019). Penerapan Model Pembelajaran Guided Inquiry dengan Pendekatan Nested untuk Melatihkan Keterampilan Berpikir Kritis Siswa Kelas XI SMA pada Materi Laju Reaksi. Unesa Journal, 8(2), 250-258.

Belawati. (2020). Buku Pembelajaran Online. Kementerian Pendidikan dan Kebudayaan. BSNP. (2014). Penilaian Buku Teks Pelajaran Untuk Siswa SMA/MA. Badan Standar Nasional Pendidikan.

Damaianti, O., Mawardi, M., \& Oktavia, B. (2019). Development of guided inquirybased worksheets on colloidal material for chemistry learning grade XI in senior high school. International Jurnal of Progressive Sciences and Technologies (IJIPSAT), 14(1), 13-19.

Depdiknas. (2008). Panduan Pengembangan Bahan Ajar. Direktorat Pembinaan Sekolah Menengah Atas Direktorat Jenderal Manajemen Pendidikan Dasar dan Menengah Departemen Pendidikan Nasional.

Facione, P.A. (2011). Critical Thinking : What It Is and Why It Counts. Insight assessment. California: California Academic Press. 
Firdaus, M., \& Wilujeng, I. (2018). Pengembangan LKPD Inkuiri Terbimbing untuk Meningkatkan Keterampilan Berpikir Kritis dan Hasil Belajar Peserta Didik. Jurnal Inovasi Pendidikan IPA, 4(1), 2640.

Hake, R. (1998). Interactive Engagment Versus Tradisional Methods. A Six Thousand Student Survey of Mecanics Test Dta for Introductory Physics Courses. American Journal Physics, 64-74.

Handarini, O. I. (2020). Pembelajaran Daring Sebagai Upaya Study From Home (SFH) Selama Pandemi Civid-19. Jurnal Pendidikan Administrasi Perkantoran (JPAP), 8(3).

Harjono, A., Gunawan, \& Sutrio. (2015). Multimedia Interaktif dalam Pembelajaran Konsep Listrik Bagi Calon Guru. Jurnal Pendidikan Fisika Dan Teknologi, 1(1), 914.

Kemendikbud. (2020). Penyesuaian Kebijakan Pembelajaran di Masa Pandemi COVID19. Kementerian Pendidikan dan Kebudayaan.

Kurniawan, T. D. (2016). Pengaruh Penggunaan Media Video Pembelajaran terhadap Prestasi Belajar Ilmu Pengetahuan Sosial. Trihayu: Jurnal Pendidikan, 3(1), 21-26.

Kusuma, R. M., Wahidin, \& Gloria, R. Y. (2015). Penerapan Pembelajaran Terpadu Tipe Nested (Tersarang) Untuk Meningkatkan Literasi Sains Siswa Pada Konsep Ekosistem Di Kelas X Sma Negeri 5 Kota Cirebon. Scientiae Educatia, 5(2), 1-17.

Munfaricha, F., \& Ismono. (2019). Penerapan Lembar Kerja Siswa (LKS) Berbasis Inkuiri Terbimbing dalam Meningkatkan Ketrampilan Berpikir Kritis Siswa pada Sub Materi Faktor-faktor yang Mempengaruhi Laju Reaksi. Unesa Journal, 53(9), 187193.

Mustain, I. (2015). Kemampuan Membaca dan Interpretasi Grafik dan Data: Studi Kasus pada Siswa Kelas 8 SMPN. Scientiae Educatia, 5(2).

Nurdyansyah, \& Fahyuni, E. F. (2016). Inovasi Model Pembelajaran Sesuai Kurikulum 2013. Sidoarjo: Nizamia Learning Center.

OECD. (2019). PISA 2018 Assessment and Analytical Framework. Paris: OECD Publishing.

Prasetyowati, E. N., \& Suyatno. (2016). Peningkatan Penguasaan Konsep dan Keterampilan Berpikir Kritis Siswa Melalui
Implementasi Model Pembelajaran Inkuiri pada Materi Pokok Larutan Penyangga. Jurnal Kimia Dan Pendidikan Kimia (JKPK), 1(1), 67-74.

Prastowo, Andi. (2015). Panduan Kreatif Membuat Bahan Ajar Inovatif. Yogyakarta: Diva Press.

Rakhmawati, P., \& Siregar, A. (2020). Pembelajaran Berbasis Google Classroom, Google Meet dan Zoom Guru SMP Negeri 2 Batubara. Jurnal Pengabdian Kepada Masyarakat, 1(4), 410-416.

Riduwan. (2015). Dasar-dasar Statistika. Bandung: Alfabeta.

Santrock, J. W. (2008). Psikologi Pendidikan. Salemba Humanika.

Sulistiani, E., \& Masrukan. (2016). Pentingnya Berpikir Kritis dalam Pembelajaran Matematika untuk Menghadapi Tantangan MEA. Seminar Nasional Matematika $X$ Universitas Semarang 2016, 605-612.

Sutama, I. N., Arnyana, M., \& Swasta, M. (2014). Pengaruh Model Pembelajaran Inkuiri Terhadap Ketrampilan Berpikir Kritis dan Keterampilan Proses Sains Pada Pelajaran Biologi Kelas XI IPA SMA Negeri 2 Amlapura. Jurnal Pendidikan Dan Pembelajaran IPA Indonesia, 4(1).

Wijaya, E. Y., Sudjimat, D. A., \& Nyoto, A. (2016). Transformasi Pendidikan Abad 21 Sebagai Tuntutan Pengembangan Sumber Daya Manusia Di Era Global. Prosiding Seminar Nasional Pendidikan Matematika 2016. 263-278. 